\title{
A SURVEY OF 501 CASES OF BRONCHOGENIC CARCINOMA
}

\author{
BY
}

\author{
A. J. LEA
}

(RECEIVED FOR PUBLICATION MARCH 31, 1952)

This survey was undertaken as part of a general programme for the investigation of the possibility of an association between susceptibility to disease and eye and hair colour. No evidence of such an association in the case of bronchogenic carcinoma was found, but evidence on various other aspects of this disease was obtained, more especially statistical confirmation of views already put forward by other observers.

These data have been obtained from 501 cases of bronchogenic carcinoma which occurred in members of the armed Forces during the period 1939-50. The series is not a random one, as selection on certain lines has occurred: (1) All cases were males. (2) The age incidence was necessarily limited to the Service ages. It ranged from 18 to 62 years. (3) None of the patients is still living. (4) Only " proved " cases have been used, "proof " being here defined as (a) histological evidence, either from biopsy or post-mortem examination, or (b) post-mortem evidence of a pulmonary growth with secondary deposits in the adrenal glands. This second criterion has been adopted because of the remarkable rarity with which neoplasms other than bronchogenic carcinoma produce adrenal secondaries, and the frequency with which histologically proved bronchogenic carcinomas do produce such metastases. Fifty-two cases of this second group have been included.

These grounds of selection necessarily influence the interpretation of the data and are further considered in relation to the particular results they affect.

Many of the findings were in every way similar to those described in previously published series ; for example, previous history, clinical findings, cerebral presentation, abdominal presentation, distribution of secondaries. Only those subjects on which new data of a numerical nature have been found have been dealt with here.

\section{Association With Eye and Hair Colour}

Eye and hair colours have been considered separately, and also the combination of these two

\begin{tabular}{|c|c|c|c|c|c|}
\hline & $\begin{array}{l}\text { Ana- } \\
\text { plastic }\end{array}$ & $\begin{array}{l}\text { Squam- } \\
\text { ous }\end{array}$ & $\begin{array}{l}\text { Adeno- } \\
\text { car- } \\
\text { cinoma }\end{array}$ & $\begin{array}{c}\text { Not } \\
\text { Stated }\end{array}$ & Totals \\
\hline \begin{tabular}{l}
\multicolumn{4}{c}{ Age at Onset of Sy } \\
Radiotherapy $\ldots$ \\
Pneumonectomy \\
Other forms of treatment
\end{tabular} & $\begin{array}{c}\text { mptoms } \\
76 \\
9 \\
1\end{array}$ & $\begin{array}{r}\text { Krown } \\
29 \\
7 \\
0\end{array}$ & $\begin{array}{l}4 \\
1 \\
0\end{array}$ & $\begin{array}{r}20 \\
4 \\
0\end{array}$ & $\begin{array}{r}129 \\
21 \\
1\end{array}$ \\
\hline Total treated $\ldots$ & 86 & 36 & 5 & 24 & 151 \\
\hline $\begin{array}{l}\text { Not known if treatment } \\
\text { was given } \ldots \\
\text { No specific treatment for } \\
\text { carcinoma .. }\end{array}$ & $\begin{array}{r}19 \\
134\end{array}$ & $\begin{array}{r}4 \\
31\end{array}$ & $\begin{array}{r}1 \\
25\end{array}$ & $\begin{array}{r}6 \\
62\end{array}$ & $\begin{array}{r}30 \\
252\end{array}$ \\
\hline $\begin{array}{c}\text { Totals for "“ age at onset } \\
\text { known" } \\
\end{array}$ & 239 & 71 & 31 & 92 & 433 \\
\hline 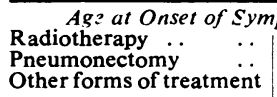 & $\begin{array}{c}\text { ptoms no } \\
3 \\
2 \\
1\end{array}$ & \begin{tabular}{|c|} 
ot $K$ rown \\
6 \\
2 \\
1
\end{tabular} & $\begin{array}{l}0 \\
0 \\
0\end{array}$ & $\begin{array}{l}1 \\
1 \\
0\end{array}$ & $\begin{array}{r}10 \\
5 \\
2\end{array}$ \\
\hline Total treated $\ldots \quad \ldots$ & 6 & 9 & 0 & 2 & 17 \\
\hline $\begin{array}{l}\text { Not known if treatment } \\
\text { was given } \ldots \\
\text { No specific treatment for } \\
\text { carcinoma } \ldots\end{array}$ & $\begin{array}{r}0 \\
22\end{array}$ & 9 & 5 & $\begin{array}{r}1 \\
12\end{array}$ & $\begin{array}{r}3 \\
48\end{array}$ \\
\hline $\begin{array}{c}\text { Totals for " age at onset } \\
\text { not known" }\end{array}$ & 28 & 20 & 5 & 15 & 68 \\
\hline $\begin{array}{l}\text { Totals for treated cases } \\
\text { Totals for treated not } \\
\text { known cases } \\
\text { Totals for untreated cases }\end{array}$ & $\begin{array}{r}92 \\
19 \\
156\end{array}$ & $\begin{array}{r}45 \\
6 \\
40\end{array}$ & $\begin{array}{r}5 \\
1 \\
30\end{array}$ & $\begin{array}{r}26 \\
7 \\
74\end{array}$ & $\begin{array}{r}168 \\
33 \\
270 \\
\end{array}$ \\
\hline Grand TOTALS $\ldots$ & 267 & 91 & 36 & 107 & 501 \\
\hline
\end{tabular}

factors using the classification proposed by MacConaill (1941), namely, blondes, brunettes, glaucopes, and cyanopes. A control series of 5,000 cases of injuries drawn from the same age groups and geographical areas was made and compared with those of bronchogenic carcinoma. The series of bronchogenic carcinoma has also been investigated for the possibility of an association between eye and hair colour and histological type of carcinoma, presence of adrenal secondaries, length of survival in untreated cases, and length of survival in treated cases. A small excess of brunettes was found in the incidence of the disease, presence of adrenal secondaries, shorter survival, both in treated and untreated cases, but none of these differences approached a significant figure. 
Anatomical Site

In 222 cases $(47.7 \%)$ the left lung was considered to be the site of the primary growth ; in 243 cases $(52.3 \%)$ the right lung: in 36 cases the side of origin could not be determined because of advanced disease. Examination of these figures gave $x^{2}=0.47$, for $\mathrm{n}=1$, with $\mathrm{P}$ between 0.3 and 0.5. The difference is not significant.

\section{Age at Onset of Symptoms}

Here it must be remembered that the age range of the series was only 18 to 62 years, and that therefore comparison with other unselected series could not be made. In 68 cases there was a continuous history of chest symptoms extending over many years, which made it impossible to assign a date to the onset of symptoms referable to the carcinoma. However, it is of interest to note that out of 433 cases in which a date could be given to the onset of symptoms, 67 of the patients were aged 30 or under, and 20 were aged 25 or under. The youngest was 18 . This confirms the statement made by Willis (1948) that "the disease is not very uncommon in young people".

\section{Age Incidence of the Different Histologicai TYPES}

Geschickter and Denison (1934) and Frissell and Knox (1937) discussed the association of squamous-celled carcinoma of the bronchus with the older age groups.

TABLE II

ACiE AT FIRST SYMPTOMS RELATED TO HISTOLOGICAL TYPE

\begin{tabular}{|c|c|c|c|}
\hline & Anaplastic & $\begin{array}{l}\text { Squamous- } \\
\text { celled }\end{array}$ & $\begin{array}{l}\text { Adeno- } \\
\text { carcinoma }\end{array}$ \\
\hline $\begin{array}{l}\text { Number of cases } \\
\text { Mean age at onset (years) }\end{array}$ & $\begin{array}{l}239 \\
37 \cdot 8\end{array}$ & $\begin{array}{l}71 \\
41 \cdot 2\end{array}$ & $\begin{array}{l}31 \\
38 \cdot 0\end{array}$ \\
\hline
\end{tabular}

Comparison of the data for squamous-celled and adenocarcinoma showed no significant difference, possibly because of insufficient material. Comparison of the data for squamous-celled and anaplastic types gave the difference between the mean ages at onset as $3.40 \pm 0.59$ years, 5.8 times the standard error. This provides statistical confirmation of the view that squamous-celled carcinoma of the bronchus has a later date of onset than the anaplastic type. The age limits of the series are of importance in this respect, as the older age groups are not as well represented in the Services as are the younger. It is very probable that the age difference shown is an underestimate.

\section{RESUlTS OF RADIOLOGY}

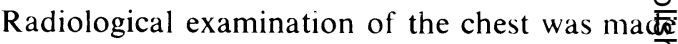
in 462 cases $(92.4 \%)$. In 148 cases $(32 \%$ of tho radiographed) a diagnosis was given by the radiologist, subsequently shown to be correct in $\frac{15}{3}$ $(50.7 \%)$ of them (Table III).

\section{TABLE III}

RADIOLOGICAI. DIAGNOSES OI IHS ( ASES*

\begin{tabular}{|c|c|c|c|}
\hline Diagnosis & & Number of Cases & Percentage \\
\hline Neoplasm, pulmonary & . & 75 & $50 \cdot 7$ \\
\hline Tuberculosis .. & $\ldots$ & 17 & 11.5 \\
\hline Bronchiectasis & $\cdots$ & 7 & $4 \cdot 7$ \\
\hline Pneumonia & . & 32 & $21 \cdot 6$ \\
\hline Lung abscess ... & . & 3 & $2 \cdot 0$ \\
\hline Inflammatory, type & wn & 6 & $4 \cdot 1$ \\
\hline Neoplasm. secondary & . & 6 & $4 \cdot 1$ \\
\hline Chronic bronchitis & . & 2 & $1 \cdot 4$ \\
\hline
\end{tabular}

* In the remaining 314 cases a description of the radiologice findings was given but without diagnosis.

Simpson (1929) described 52 cases of this disea实 in which a diagnosis was made as a result of radio logical examination. Twenty-nine of these 156 \% were diagnosed as neoplasm. Bryson and Spencer (1951) stated that the initial radiological diagnos was incorrect in $60.4 \%$ of their series of 804 case It appears that there has not been any change $\overline{\mathrm{g}}$ the reliability of radiological diagnosis of thes disease since 1929.

\section{RESUlts OF BRONCHOSCOPY AND BIOPSY}

Bronchoscopy was carried out in 288 cases. 267 of these $(92.7 \%$ ) evidence of some form bronchial abnormality was found, though this w鹿 not always recognized as neoplastic until the results of biopsy were known. In 21 cases (7.3 bronchoscopy failed to reveal any abnormalis. Biopsy was performed in 343 cases, either bronchoscopy specimens or glands, and only \$1 times $(3.2 \%)$ failed to provide evidence $\widehat{\theta}^{\dagger}$ malignancy.

\section{Accuracy of Diagnosis}

Fifteen cases $(3 \%)$ were not diagnosed correcth until post-mortem examination. This companes very favourably with previously published series: for example, Simpson's (1929), in which only 73 oit of 139 cases were correctly diagnosed during life (an error of $43 \%$ ). This supports the view the at least part of the apparent increase in the in dence of this disease is due to improvement in diagnosis.

\section{TREATMENT}

One hundred and thirty-nine cases $(27.7 \%)$ weqe treated by radiotherapy or radon. Pneumo ectomy was performed in 26 cases $(5.2 \%)$. 
lobectomy in one $(0.2 \%)$. Exploratory thoracotomy was performed in 53 cases $(10.6 \%)$, which were found to be inoperable because of mediastinal involvement. Bryson and Spencer (1951) stated that out of 752 cases, drawn from 26 hospitals formerly under the control of the London County Council, only $48(6.4 \%)$ were considered suitable for radiotherapy and six $(0.8 \%)$ for surgery. Brooks, Davidson, Price Thomas, Robson, and Smithers (1951) have estimated that fewer than 200 of the 9,000 persons dying each year in England and Wales from this disease undergo pneumonectomy $(2.2 \%)$. These figures suggest that cases of bronchogenic carcinoma in the Services came under observation and treatment at an earlier stage than those occurring in the civilian population.

\section{EFFECTS OF TREATMENT}

Prolongation of LiFE.-The greatest difficulty in dealing with this question was to decide from what date in the course of the disease the observations should begin. Stocks (1951) has pointed out that the only legitimate statistical treatment is on an actuarial basis unless it can be shown that all the patients eventually died from the disease under consideration. In the present series this obligation is fulfilled. The obvious method was to consider the duration of life from the date of the start of treatment, but this introduced two major difficulties; (1) no account was taken of how far the carcinoma had advanced before treatment began, and (2) it made comparison with a control series of untreated cases impossible. The alternative method was to consider the duration of life from the date of first symptoms. This method also took no account of the stage of the carcinoma before treatment, but it was possible to make a comparison with a control series. It is fully appreciated that the first symptoms do not coincide with the onset of malignancy, and it must therefore be emphasized that the figures presented are based on an arbitrary date of onset. On the other hand, these figures are, for two reasons, heavily biased against prolongation of life; (1) they take no account of patients who are still living as a result of treatment, and (2) in the recent paper of Brooks and others (1951) a distinction was drawn between cases receiving radical radiotherapy and those receiving only palliative treatment. This distinction has not been found possible in this series, so that an unknown number of advanced cases is included as having been treated, whereas in all probability they might justifiably have been excluded. As an example, 22 of the 53 cases which were found at thoracotomy to be inoperable were given palliative radiotherapy. Such cases have all been included as "treated."

In 151 treated cases the evidence allowed a date to be given to the onset of symptoms. The mean duration of life in these cases was 14.0 months (extremes one to 105 months). Two hundred and fifty-two patients who received no specific treatment for carcinoma had a mean duration of life from the date of onset of symptoms of 6.5 months (extremes one to 59 months). Comparison of these figures gives the difference of the means as $7.5 \pm 1.2$ months, the difference being 6.25 times its standard error.

Comparison was made between 129 cases treated by radiotherapy and 21 in which pneumonectomy was performed, using Student's " $t$ " test (Fisher, 1950). The mean duration of life in the cases treated by radiotherapy was 13.3 months (extremes one to 94 months), in the cases treated by pneumonectomy 18.8 months (extremes two to 105 months). Thus " $t$ " was found to be 1.82 , which, with $n=148$, gave a value for $P$ between 0.05 and 0.1 , which is not significant.

Finally, cases treated by radiotherapy were compared with the untreated series. The difference of the means was found to be $6.8+1.2$ months, 5.7 times its standard error.

From these results it is evident that treatment both by pneumonectomy and radiotherapy produced a significant prolongation of life.

The possibility of an association between age at onset and duration of life, in both treated and untreated cases, was investigated. No significant differences were found.

Anaplastic and SQuamous-celled Bronchial Carcinoma.-The effect of treatment on the different histological types was also considered.

TABLE IV

EFFECT OF TREATMENT ON DURATION OF LIFE IN DIFFERENT HISTOLOGICAL TYPES

\begin{tabular}{|c|c|c|c|c|}
\hline & & \multicolumn{3}{|c|}{ Mean Duration in Months } \\
\hline & & Untreated & $\begin{array}{l}\text { Radio- } \\
\text { therapy }\end{array}$ & $\begin{array}{l}\text { Pneumon- } \\
\text { ectomy }\end{array}$ \\
\hline $\begin{array}{l}\text { Anaplastic } \\
\text { Squamous-ce!led } \\
\text { Adenocarcinoma }\end{array}$ & $\begin{array}{l}\cdots \\
\cdots\end{array}$ & $\begin{array}{l}5 \cdot 2(134)^{*} \\
10 \cdot 8(31) \\
7 \cdot 9(25)\end{array}$ & $\begin{array}{l}11.0(76) \\
17 \cdot 8(29) \\
31 \cdot 8(4)\end{array}$ & $\begin{array}{r}11 \cdot 1(9) \\
30 \cdot 1(7) \\
7 \cdot 0(1)\end{array}$ \\
\hline
\end{tabular}

It will be seen that there is a marked difference between the mean durations of untreated cases of anaplastic and squamous-celled carcinoma. These data have been subjected to the " $t$ " test with the result that " $t "=4.86, n=163$, and $P$ is less than 0.001 . Adenocarcinomas were too few for statistical treatment to be justified. 
The difference in the duration of life between anaplastic and squamous-celled carcinomas treated by radiotherapy was also considered. Calculation gave " $\mathrm{t} "=3.05, \mathrm{n}=103$, and $\mathrm{P}$ less than 0.01 . The number of cases treated by pneumonectomy was too small for statistical treatment.

The difference in age at onset between these two types of bronchogenic carcinoma has already been discussed. The evidence that cases of squamous-celled carcinoma have a later date of onset and a longer survival period, in both treated and untreated cases (all three differences being statistically significant), than have cases of the anap!astic type suggests that there are real grounds for regarding these histological types as separate entities. It is of interest to note that it was not possible to give a date of onset in 20 cases of squamous-celled carcinoma out of a total of 91 $(22 \%)$ because of a long history of pulmonary symptoms. In cases of anaplastic carcinoma the unknown onset group was only 28 out of 267 $(10.3 \%)$. This suggests the possibility of the squamous-celled type having its origin in chronic pulmonary irritation.

\section{Atherosclerosis}

Wanscher, Clemmesen, and Nielsen (1951) have produced evidence of a negative correlation between carcinomas of all types and atherosclerosis. The present material has been graded for 115 cases in which the state of the arteries was discussed in detail, as far as possible in the manner laid down by these authors. Cases in which the descriptions were limited to such statements as "heart and vessels NAD" have not been included.

TABLE V

DEGREE OF ATHEROSCLEROSIS AS DEFINED BY WANSCHER AND OTHERS (1951) IN CASES OF BRONCHOGENIC CARCINOMA

\begin{tabular}{lc|c|c|c|c}
\hline Group.. &.. & I & II & III & IV \\
\hline Number of cases &.. & 89 & 20 & 6 & 0 \\
\hline
\end{tabular}

Comparison of these data with those of Wanscher and others for non-cancerous cases of the same age groups gave $x^{2}=48.1, \mathrm{n}=3, \mathrm{P}$ less than 0.001 . Further statistical treatment was not considered to be justified, as the degree of atherosclerosis in the present series was based on the opinions of many different pathologists. Nevertheless, the evidence does provide confirmation of the findings of Wanscher and others and suggests that further investigation of this curious repulsion between carcinoma and atherosclerosis would be of considerable interest.

\section{Peripheral Neuritis}

Unexplained peripheral neuritis in association with bronchogenic carcinoma has been describedब by Lennox and Prichard (1950). Eleven such cases were found in the present series, an inci- $-\infty$ dence of $2.2 \%$, which agrees very well with $1.7 \%$ found by Lennox and Prichard. As these cases were very similar to those already published by the above observers details have not been given $\Rightarrow$ Points of interest were that in eight of the cases the neuritis was the first symptom, in none of them was any evidence found of metastases inf brain or cord, in none of them was there anyor evidence of enlarged glands or other causes of pressure on nerve trunks, four of the cases showect improvement of the peripheral neuritis while the carcinoma worsened. Unfortunately there were्ठ no histological investigations of the affected nerves 3

A control series was made of 553 cases of proved neoplasm arising in tissues other than the bronchus. Cases of cerebral and spinal tumoury were excluded because of the obvious difficulties in the diagnosis of peripheral neuritis had it beeno present. Similarly cases with metastases in thes central nervous system were not used. Apart fromo these exclusions the cases were selected only foro histological proof of neoplasia. Of this series o[ 553 cases none showed any signs or symptoms $\vec{B}$ which could be interpreted as peripheral neuritis 3

Comparison of this control series was made with the 501 cases of bronchial carcinoma using Yates's correction 'for continuity. With $\mathrm{n}=1$, the value found for $x^{2}$ was 11.38 , from which $\mathrm{P}$ is less than 0.001 . This provides further confirmation for the view that the association between broncho genic carcinoma and peripheral neuritis is not. merely coincidental, though it throws no fresto light on the cause.

\section{Peptic Ulcer}

In 27 cases, $12.1 \%$ of those in which a necrops was recorded, there was evidence of peptic ulcerfs ation. Ivy, Grossman, and Bachrach (1950) have estimated that the necropsy incidence of this con dition in western Europe ranges from 5 to $10 \%$ In view of the recent statements on the association between cigarette smoking and bronchogenis carcinoma (Daff, Doll, and Kennaway, 1951) and the long-recognized association between the same habit and peptic ulcer, a higher incidence of peptic ulcer in cases of bronchogenic carcinoma than iro the general population would not be surprising As at the majority of the necropsies it seems than no special search was made for peptic ulcer stomach and duodenum being frequently described 
as "NAD" or " no growth seen," it is very probable that these 27 cases are an under-estimate and do not represent the true incidence. In one case, very fully described, there were three active ulcers, two gastric and one duodenal. In another there were four active ulcers, three gastric and one duodenal. In neither of these cases could any histological evidence of malignancy of the ulcers be found.

\section{SUMMARY}

A series of 501 proved cases of bronchogenic carcinoma occurring in Service personnel has been described. Evidence has been presented on (1) prolongation of life by treatment, (2) differences between anaplastic and squamous-celled carcinomas, (3) the negative correlation with atherosclerosis, (4) the association with peripheral neuritis. The association with peptic ulcer has been discussed, and also the results of radiological and bronchoscopic investigations. No evidence of an association with eye and hair colour was found.
The work has been carried out with the aid of a grant from the Government Grant Committee of the Royal Society.

I wish to acknowledge my indebtedness to the Director-General of Medical Services of the Ministry of Pensions for permission to publish the material extracted from Service case sheets.

\section{REFERENCE;}

Brooks, W. D. W., Davidson, M., Thomas, C. Price, Robson. K., and Smithers, D. W. (1951). Thorax, 6, 1.

Bryson, C. C., and Spencer, H. (1951). Quart. J. Med., n.s. 20.173.

Daff, M. E., Doll, R., and Kennaway, E. L. (1951). Brit. J. Cancer, 5,1 .

Fisher, R. A. (1950). Statistical Methods for Research Workers 11 th ed. Oliver and Boyd, Edinburgh.

Frissell, L. F., and Knox, L. C. (1937). Amer. J. Cancer, 30,

Geschickter, C. F., and Denison, R. (1934). Ibid., 22, 854.

Ivy, A. C., Grossman, M. I., and Bachrach, W. H. (1950). Peptic Ulcer. Blakiston Co., Philadelphia.

Lennox, B., and Prichard, S. (1950). Quart. J. Med., n.s., 19, 97.

MacConaill, M. A. (1941). Ann. Eugen., Camb., 11, 173.

Simpson, S. L. (1929). Quart. J. Med., 22, 413.

Stocks, P. (1951). British Empire Cancer Campaign, 28th Annual Report, 1950 , p. 323.

Wanscher, O., Clemmesen, J., and Nielsen, A. (1951). Brit. J. Cancer, 5, 172.

Willis, R. A. (1948). Pathology of Tumours. Butterworth \& Co., London.

\section{SCHOLARSHIPS IN AID OF SCIENTIFIC RESEARCH}

The Council of the British Medical Association is prepared to receive applications for Research Scholarships, as follows:

An Emest Hart Memorial Scholarship, of the value of $£ 250$.

A Walter Dixon Scholarship, of the value of $£ 250$.

One or More Research Scholarships, each of the value of $£ 200$.

These scholarships are given to candidates whom the Science Committee of the Association recommends as qualified to undertake research in any subject (including State medicine) relating to the causation, prevention, or treatment of disease.

Each scholarship is tenable for one year, beginning on October 1, 1953. A scholar may be reappointed for not more than two additional terms. A scholar is not necessarily required to devote the whole of his or her time to the work of research, but may be a member of H.M. Forces or may hold a junior appointment at a university, medical school, or hospital, provided the duties of such appointment will not, in the opinion of the Science Committee, interfere with his or her work as a scholar.

Applications for scholarships must be made not later than March 31, 1953, on the prescribed form, a copy of which will be supplied on application to the Secretary, British Medical Association, B.M.A. House, Tavistock Square, London, W.C.1.

Applicants are required to furnish the names of three referees who are competent to speak as to their capacity for the research contemplated. 